\title{
Persepsi Masyarakat tentang Haramnya Investasi di Pasar Modal Syariah
}

\author{
Noor Laili Hidayah1, Ghina Aslicha2, Kharis Fadlullah Hana ${ }^{3}$ \\ Institut Agama Islam Negeri Kudus \\ noorlaili2222@gmail.com¹, ghina.a99@gmail.com², \\ kharis@iainkudus.ac.id ${ }^{3}$
}

\begin{abstract}
Public knowledge must also be comprehensive with the times. People are already familiar with the word "investment". However, everyone's perception of investing in the Islamic capital market is different. The negative public perception about the illicit investment in the Islamic capital market should not exist. Many people think about halal or illicit investment that caused a lot of debate. Halal perception comes from people who have been well educated and deeply educated. Unlawful perception arises from the lack of public education about all aspects that exist in the Islamic capital market. The purpose of this study is to prove that negative perceptions that mention investment is an unlawful activity is wrong and changing that notion into investment is a halal activity. The results of this study indicate that some people who have negative perceptions come from people who have not been educated about investing in the Islamic capital market. So, public education about investment in the Islamic capital market on all aspects needs to be improved, not only at the academic level but other aspects so that debate in the community about halal or illicit investment in the Islamic capital market need not be there.
\end{abstract}

Keywords: Education, Halal, Illicit, Investment, Sharia Capital Market

\begin{abstract}
Abstrak
Masyarakat sudah tidak asing mendengar kata "investasi". Namun, persepsi setiap orang tentang investasi di pasar modal syariah berbeda. Persepsi negatif masyarakat mengenai haramnya investasi di pasar modal syariah tidak seharusnya ada. Banyak anggapan masyarakat tentang halal atau haramnya investasi yang menimbulkan banyak perdebatan. Persepsi halal berasal dari masyarakat yang telah teredukasi dengan baik dan mendalam. Persepsi haram muncul akibat dari kurangnya edukasi masyarakatmengenai semua aspek yang ada dalam pasar modal syariah. Tujuan dari penelitian ini adalah untuk membuktikan bahwa persepsi negatif yang menyebutkan investasi merupakan kegiatan yang haram adalah salah dan merubah anggapan tersebut menjadi investasi adalah suatu kegiatan yang halal. Hasil dari penelitian ini menyebutkan bahwa sebagian masyarakat yang memiliki persepsi negatif berasal dari masyarakat yang belum teredukasi mengenai investasi di pasar modal syariah. Jadi, edukasi masyarakat mengenai investasi di pasar modal syariah terhadap semua aspek perlu ditingkatkan, bukan hanya di tingkat akademisi melainkan aspek lainnya agar perdebatan di masyarakat mengenai halal atau haramnya investasi di pasar modal syariah tidak perlu ada.
\end{abstract}


Kata Kunci: Edukasi, Halal, Haram, Investasi, Pasar Modal Syariah

\section{PENDAHULUAN}

Seiring perkembangan zaman, nyatanya investasi di pasar modal syariah masih kurang popular atau booming di masyarakat. Sehingga jika dihitung, hanya sedikit masyarakat yang berkecimpung di dunia pasar modal syariah (Selasi, 2018). Hal tersebut disebabkan adanya persepsi negatif bahwa investasi di pasar modal syariah hukumnya haram karena adanya spekulasi. Padahal hakikatnya spekulasi bukanlah suatu investasi. Dilihat dari bentuknya memang sedikit memiliki kemiripan, namun perbedaannya terletak pada spirit yang menjiwai investasi. Pertama, investor membeli sekuritas untuk berperan langsung dalam bisnis, namun para spekulan cenderung membeli sekuritas untuk mendapat keuntungan jika dijual di masa depan. Kedua, spekulasi telah membuat unearned income (penghasilan diterima di muka) menjadi meningkat bagi masyarakat tanpa mereka ikut berkontribusi apapun. Ketiga, spekulasi menjadi penyebab terjadinya krisis keuangan (Dyarini, 2012).

Persepsi negatif tersebut muncul karena kurangnya edukasi masyarakat, yaitu sosialisasi tentang pasar modal syariah, begitu juga dengan pemahaman mereka tentang sistem pasar modal syariah. Padahal, pasar modal syariah dapat dimanfaatkan oleh siapapun tanpa melihat latar belakang suku, agama, dan ras tertentu sehingga dapat dikatakan memiliki sifat universal (umum). Kegiatan pasar modal syariah merupakan kegiatan penyertaan modal atau jual beli efek yang termasuk dalam kelompok muamalah, sehingga transaksi dalam pasar modal syariah diperbolehkan sepanjang tidak ada larangan menurut syariah dan kegiatannya termasuk halal. Sedangkan kegiatan muamalah yang dikatakan haram adalah kegiatan manipulasi dan spekulasi yang di dalamnya mengandung unsur maysir, gharar, dan riba (Selasi, 2018).

Penelitian yang dilakukan oleh Diana Wiyanti mengkaji tentang perspektif hukum Islam terhadap pasar modal syariah dan perbedaan antara investasi dan spekulasi berdasarkan syariah, sehingga dapat diketahui konsep investasi menurut hukum Islam (Wiyanti, 2013). Selanjutnya, penelitian yang dilakukan oleh Ferry Husnul Mubarok menjelaskan bahwa Literasi Keuangan dalam Roadmap Pasar Modal Syariah di tahun 2015-2019, kebanyakan masyarakat $>90 \%$ masih belum mengetahui investasi di pasar modal syariah secara mendalam. Hal tersebut berdampak pada penggunaan instrumen pasar modal syariah $>1 \%$, sehingga penggunaannya dapat dikatakan masih sedikit (Mubarok, 2018).

Selanjutnya, penelitian yang dilakukan oleh Zulfadhly Lutfi A. Lopa dan Sri Astuti Ratnasari Manggu yang menggunakan analisis linear berganda menjelaskan bahwa persepsi, pengetahuan, dan preferensi risiko 
berpengaruh terhadap minat masyarakat (Lopa \& Manggu, 2019). Untuk itu, diversifikasi dari penelitian ini berusaha untuk membuktikan bahwa perdebatan-perdebatan tentang haramnya berinvestasi di pasar modal syariah muncul karena pengetahuan masyarakat terhadap pasar modal syariah dikatakan kurang. Dan dengan adanya penelitian ini, persepsi negatif masyarakat tentang haramnya investasi di pasar modal syariah dapat diluruskan.

\section{KAJIAN LITERATUR}

\section{Behavioral Finance Theory}

Behavioral Finance Theory merupakan suatu teori yang mengkaji faktor-faktor psikologis yang mempengaruhi investor dalam mengambil sebuah keputusan untuk berinvestasi (Manulife Asset Management, 2015: 1). Menurut Ricciardi, behavioral finance adalah ilmu yang menjelaskan berbagai interaksi disiplin ilmu yang secara terus menerus atau berkelanjutan, teori ini dibangun atas dasar asumsi, ide, perilaku ekonomi, sifat, kesukaan, dan lainnya (Ricciardi \& Simon, 2000: 2).

Perilaku investor dipengaruhi oleh seberapa besar informasi diterima. Dapat diartikan jika reaksi dapat berbeda terhadap sumber informasi yang sama, hal tersebut bergantung pada pemahaman terhadap suatu informasi. Yang dalam hal ini sumber informasi dapat diperoleh dari laporan keuangan (Puspitaningtyas, 2013).

\section{Persepsi}

Stephen P. Robbins mendefinisikan persepsi sebagai a process by which individuals organize and interpret their sensory impessions in order to give meaning to their environment. Persepsi diasumsikan sebagai suatu proses yang ditempuh individu untuk mengorganisasikan, menafsirkan dan menginterpretasi kesan-kesan indra agar mampu memberikan arti bagi lingkungan. Robbins juga mengkatagorikan faktor-faktor yang mempengaruhi dalam menafsirkan kesan-kesan indra menjadi suatu persepsi menjadi tiga faktor antara lain:

a. Faktor dari karakteristik pribadi atau pemersepsi

Misal: motif, sikap, kepentingan, ekspektasi, dan pengalaman.

b. Faktor dalam target

Misal: Inovasi, gerakan, bunyi, suara, latar belakang, kedekatan, dan kesamaan

c. Faktor situasional (Simbolon, 2008: 53)

Dari faktor situasional, terdapat faktor keadaan sosial yang dipengaruhi oleh pembedaan-pembedaan di masyarakat atau lebih dikenal sebagai dialektika (Malik, 2017: 74).

Persepsi diartikan sebagai anggapan yang melatarbelakangi seseorang memutuskan untuk berinvestasi syariah merupakan sesuatu 
yang diharamkan atau tidak. Dengan keputusan berinvestasi tersebut maka seseorang sudah berpersepsi bahwa investasi bukan sesuatu yang diharamkan.

3. Investasi

Menurut Alexander dan Sharpe, investasi sebagai pengorbanan nilai tertentu yang digunakan untuk mendapatkan nilai pada masa yang akan datang, namun belum diketahui besarnya. Sementara, Yogiyanto menyatakan bahwa investasi merupakan penundaan konsumsi saat ini untuk digunakan dalam produksi yang efisien selama suatu periode tertentu. Tandelin mendefinisikan invetasi sebagai suatu komintmen mengenai sejumlah sumber dana, dan sumber dana lain dengan tujuan memperoleh keuntungan di masa depan (Putra, 2018: 50). Investasi sendiri merupakan bagian dari aktivitas ekonomi yang termasuk muamalah maliyah, maka berlakulah kaidah fikih muamalah, yaitu pada dasarnya semua bentuk muamalah termasuk aktivitas ekonomi diperbolehkan kecuali terdapat dalil yang mengharamkannya. Menurut fatwa DSN MUI No. 80/DSNMUI/III/2011 terdapat transaksi-transaksi yang dilarang karena bertentangan dengan prinsip syariah seperti: maisyir, gharar, riba, batil, bay'i ma'dum, ihtikar, dan lainnya (Pardiansyah, 2017: 351). Dalam hal ini berfokus pada investasi syariah yang menjadi fokus utama.

\section{Pasar Modal Syariah}

Pasar modal syariah merupakan salah satu lembaga keuangan yang mempunyai peran strategis karena digunakan sebagai sumber dana jangka panjang dengan tujuan pasar modal syariah menurut pandangan Islam yaitu menciptakan pasar modal yang "beretika dan adil". Seluruh transaksi di pasar modal harus dilaksanakan sesuai dengan norma etika Islam yang telah diatur dalam syariah. Pasar modal yang Islami adalah pasar modal yang ideal, yaitu yang memenuhi unsur etik, fair/ transparan dan adanya unsur efisien (Wiyanti, 2013: 247). Dalam kaitannya dengan investasi Pasar Modal Syariah merupakan tempat atau wadah yang digunakan dalam bertransaksi pada sebuah investasi.

\section{METODE PENELITIAN}

Penelitian ini merupakan jenis penelitian kualitatif deskriptif yang berupaya mendeskripsikan, mencatat, analisis dan menginterpretasikan kondisi yang sekarang ini terjadi atau ada. Metode pendekatannya menggunakan pendekatan fenomenologi yang merupakan salah satu jenis metode penelitian kualitatif yang berisi gagasan pemikiran terhadap gejala-gejala dalam berbagai dinamika pengalaman-pengalaman subjek 
yang member makna tentang suatu peristiwa (Farid \& Adib, 2018). Sumber data : primer dan sekunder. Teknik pengumpulan data:

1. Wawancara terhadap masyarakat yang sudah memiliki edukasi pasar modal syariah dan masyarakat yang belum teredukasi pasar modal syariah. Teknik analisis data dilakukan secara analisa deskriptif fenomena berupa sajian dalam bentuk uraian.

2. Library research, yaitu dengan mengkaji teori-teori investasi di pasar modal syariah yang berhubungan dengan sosialisasi dan edukasi terhadap persepsi masyarakat yang sudah memiliki edukasi pasar modal syariah dan masyarakat yang belum teredukasi pasar modal syariah.

\section{PEMBAHASAN}

Di Indonesia, keberadaan pasar modal syariah sangat penting karena menjadi media bagi investor untuk menanamkan modalnya dalam jangka panjang (Mubarok, 2018: 122). Hal tersebut sesuai data dari Bursa Efek Indonesia (BEI) yang dikutip oleh Republika, tercatat sampai Januari 2020 total investor syariah mencapai 70.135 atau meningkat sebanyak 2,2\% dari akhir tahun 2019 yang mencapai 68.599 investor (Novita, 2020) dengan kapitalisasi Pasar Bursa Efek Indonesia dan Daftar Efek Syariah sebagai berikut:

Tabel 1. Kapitalisasi Pasar Bursa Efek Indonesia

\begin{tabular}{|c|c|c|c|c|}
\hline \multirow{2}{*}{\multicolumn{5}{|c|}{$\begin{array}{c}\text { Kapitalisasi Pasar Bursa Efek Indonesia } \\
\text { (Rp Miliar) }\end{array}$}} \\
\hline & & & & \\
\hline \multicolumn{2}{|c|}{ Tahun } & Jakarta Islamic & Indeks Saham & Jakarta Islamic \\
\hline 2000 & & $74.268,92$ & - & - \\
\hline 2001 & & $87.731,59$ & - & - \\
\hline 2002 & & $92.070,49$ & - & - \\
\hline 2003 & & $177.781,89$ & - & - \\
\hline 2004 & & $263.863,34$ & - & - \\
\hline 2005 & & $395.649,84$ & - & - \\
\hline 2006 & & $620.165,31$ & - & - \\
\hline 2007 & & $1.105 .897,25$ & - & - \\
\hline 2008 & & $428.525,74$ & - & - \\
\hline 2009 & & $937.919,08$ & - & - \\
\hline 2010 & & $1.134 .632,00$ & - & - \\
\hline 2011 & & $1.414 .983,81$ & $1.968 .091,37$ & - \\
\hline 2012 & & $1.671 .004,23$ & $2.451 .334,37$ & - \\
\hline 2013 & & $1.672 .099,91$ & $2.557 .846,77$ & - \\
\hline 2014 & & $1.944 .531,70$ & $2.946 .892,79$ & - \\
\hline
\end{tabular}


Noor Laili Hidayah, Ghina Aslicha dan Kharis Fadlullah Hana

\begin{tabular}{l|l|l|l|l}
\hline 2015 & & $1.737 .290,98$ & $2.600 .850,72$ & - \\
\hline 2016 & & $2.035 .189,92$ & $3.170 .056,08$ & - \\
\hline 2017 & & $2.288 .015,67$ & $3.704 .543,09$ & - \\
\hline 2018 & & $2.239 .507,78$ & $3.666 .688,31$ & $2.715 .851,74$ \\
\hline 2019 & & $2.318 .565,69$ & $3.744 .816,32$ & $2.800 .001,49$ \\
\hline 2020 & Januari & $2.134 .960,15$ & $3.464 .489,36$ & $2.574 .301,02$ \\
\hline
\end{tabular}

Gambar 1. Jumlah Saham Syariah dalam DES

\section{Jumlah Saham Syariah Dalam Daftar Efek Syariah (DES)}

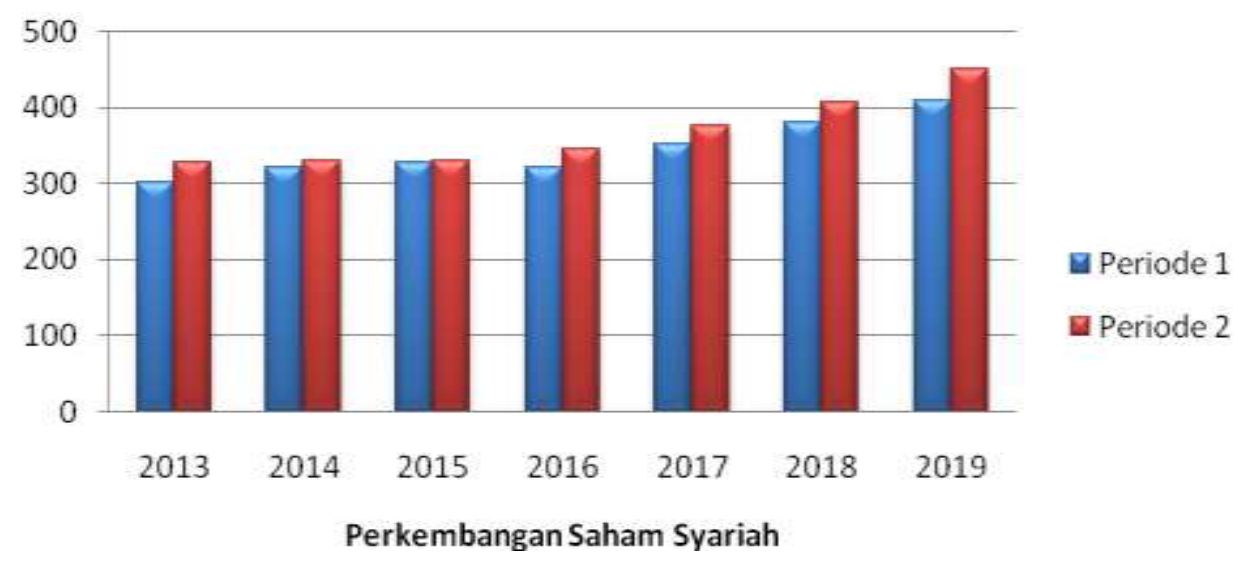

JII ditahun 2019 2.318.015,78 dan pada Januari 2020 sebesar 2.134.960,15, indeks saham syariah Indonesia di tahun 2019 sebanyak 3.774.816,32 dan di tahun 2020 sebesar 3.464.489,36, serta Jakarta Islamic Indeks 70 di tahun 2019 sebesar 2.800.001,49 dan di tahun 2020 2.574.301,02 (Direktorat Pasar Modal Syariah \& Keuangan, 2020).

Hal tersebut membuktikan bahwa dengan adanya investasi syariah dapat mengakomodasi keinginan untuk berinvestasi yang sejalan dengan nilai-nilai agama serta dapat menjadi penggerak roda perekonomian bangsa. Hal ini sesuai dengan hasil wawancara kepada Wayatul Umah sebagai berikut:

"...dengan adanya pasar modal syariah akan tercipta distribusi pendapatan yang lebih merata, peningkatan penerimaan negara melalui pajak, sarana perekonomian dan pencipta daya beli masyarakat."

Pernyataan tersebut sesuai dengan informasi yang ada di Otoritas Jasa Keuangan (OJK) tentang manfaat yang didapatkan ketika berinvestasi di Pasar Modal Syariah (www.ojk.go.id, n.d.). Manfaat dapat diperoleh 
dengan adanya investasi, berdasarkan teori Fitz Gerald manfaat kegiatan yang berkaitan dengan usaha penarikan sumber-sumber yang digunakan untuk mengadakan modal barang pada saat sekarang, selanjutnya barang modal itu akan menghasilkan aliran produk baru dimasa yang akan datang (Gerald, 1978).

\section{Persepsi kehalalan Investasi di Pasar Modal Syariah}

Pengembangan transaksi yang dijalankan di pasar modal syariah sudah berusaha disesuaikan dengan prinsip syariah, hal ini sesuai dengan pernyataan dari Rizqiya Fitriani dan M. Grisvian Gema E:

"... pasar modal syariah dikatakan halal karena sudah berusaha sesuai dengan syariat Islam, walaupun belum sepenuhnya."

\section{a. Mekanisme yang telah sesuai dengan prinsip-prinsip syariah}

Investasi di pasar modal syariah dikatakan halal karena seluruh mekanisme aktivitas pasar modal syariah terutama mengenai emiten, jenis efek yang diperdagangkan dan mekanisme perdagangannya telah sesuai dengan prinsip-prinsip syariah yaitu tidak mengandung unsur maysir, gharar, dan riba, serta adanya unsur saling ridho. Hal ini sesuai pernyataan dari informan Pandia Dewi, Angelia Mayang,Shinta Ulya Rizqiyah, dan M. Haqqul Muhkam yang mengatakan bahwa:

"...berinvestasi di pasar modal syariah tidak haram, karena produk, mekanisme transaksi serta hasilnya tidak bertentangan dan sesuai dengan prinsip syariah."

Pernyataan tersebut sesuai dengan POJK nomor 15/POJK.04/2015 mengenai penerapan prinsip syariah di pasar modal yang di dalamnya memuat pasal-pasal ketentuan umum, pihak yang melakukan kegiatan syariah di pasar modal, pelaporan, ketentuan lain, ketentuan sanksi, dan ketentuan penutup (www.ojk.go.id, n.d.).

Selanjutnya persepsi halal muncul dari mayoritas masyarakat yang telah teredukasi mengenai investasi di pasar modal syariah. Beberapa alasan melatarbelakangi anggapan halal tersebut. Diantaranya mekanisme yang telah sesuai dengan prinsip-prinsip syariah, hal ini dibuktikan dengan hasil wawancara dengan informan Noor Haidar Rini sebagai berikut:

“...pada prinsipnya investasi di pasar modal syariah dikatakan halal karena mengedepankan nilai-nilai Islami dan ada hukum Islam yang memperkuat seperti hadis, ijma', dan qiyas." 
Hal ini sesuai juga dengan informasi dasar yang ada di Otoritas Jasa Keuangan (OJK) bagian konsep dasar yang menjelaskan bahwa Penerapan prinsip syariah di pasar modal bersumber dari Al Quran sebagai sumber hukum tertinggi dan Hadits Nabi Muhammad SAW (www.ojk.go.id, n.d.).Didalam pasar modal syariah telah disebutkan dengan jelas berapa keuntungannya dan tidak boleh mengandung unsur riba serta harus disebutkan secara jelas sehingga tidak mengandung unsur gharar. Karena pada prinsipnya investasi di pasar modal syariah dikatakan halal karena mengedepankan nilai-nilai Islami dan ada hukum Islam yang memperkuat seperti hadis, ijma', dan qiyas. Serta dilakukan dengan kedua belah pihak yang saling menguntungkan.

Investasi di Pasar Modal Syariah juga tidak mengandung unsur penjudian. Hal ini dibuktikan dengan hasil wawancara dari informan bernama Reza Yulistia yang menyatakan bahwa:

"...investasi di pasar modal syariah itu halal, karena dalam pasar modal syariahmerupakan bentuk investasi dan tidak bersifat perjudian."

Sehingga dari penyataan tersebut investasi dikatakan sebagai sesuatu yang dihalalkan karena tidak mengandung unsur-unsur yang menyimpang dari ajaran Islam. Hal tersebut sesuai dengan penelitian (Hana, 2018) yang menyatakan bahwa transaksi di pasar modal syariah halal apabila sesuai dengan pedoman. Salah satu artikel yang dimuat oleh Indopremier juga menyebutkan bahwa investasi di pasar modal syariah jauh dari pelaksanaan judi baik maysir atau qimar (IPOT, 2018).

\section{b. Pengawasan yang terpercaya}

Ulama yang berwenang mengawasi di Indonesia adalah Dewan Syariah Nasional Majelis Ulama Indonesia (DSN-MUI). Mekanisme perdagangan efek bersifat ekuitas di pasar reguler bursa efek di pasar modal (Selasi, 2018: 93). Hal ini sesuai dengan hasil wawancara terhadap Rona Roikhana, Lana Kavida dan Siti Muslimah berikut:

"...investasi di pasar modal syariah halal karena semua peraturan yang berkaitan dengan pasar modal syariah sudah pasti disahkan oleh MUI dan diawasi oleh OJK (Otoritas Jasa Keuangan) serta ada 14 fatwa yang telah ditetapkan oleh Dewan Syariah Nasional Majelis Ulama Indonesia (DSN-MUI) yang berhubungan dengan pasar modal syariah Indonesia sejak tahun 2001"

Pernyataan diatas sesuai dengan informasi Otoritas Jasa Keuangan (OJK) mengenai Dasar hukum kegiatan Pasar Modal 
Syariah yang di dalamnya memuat pasar modal syariah sebagai bagian sektor keuangan yang diawasi oleh OJK. Selain itu, terdapat juga pada Visi dari OJK, yaitu menjadi lembaga pengawas industri jasa keuangan yang terpercaya (www.ojk.go.id, n.d.).

Lembaga yang berhak menentukan sebuah saham sudah sesuai prinsip syariah atau haram di Indonesia adalah DSN-MUI. Didalam pasar modal syariah, ada yang disebut Syariah Compliance Officer (SCO).SCO adalah pihak atau lembaga yang bertugas untuk menjaga agar suatu perusahaan tetap sesuai syariah.SCO ini harus mendapat persetujuan oleh DSN-MUI terlebih dahulu (Selasi, 2018: 93).

Hal ini juga sepadan dengan yang dikatakan Muhammad Ulinnuha dan Asro Fina dalam hasil wawancara sebagai berikut:

"...bagaimana bisa kegiatan di pasar modal syariah yang seluruhnya harus sesuai dengan prinsip-prinsip syariah, dan diawasi langsung oleh DPS, BAPEPAM, dan DSN-MUI bisa dikategorikan haram."

Penyataan tesebut sesuai dengan fatwa DSN MUI No. 40/DSNMUI/X/2003 tentang Pasar Modal dan Pedoman Umum Penerapan Prinsip Syariah di Bidang Pasar Modal yang berisi mekanisme kerja DSN, BPH, dan DPS (www.dsn.mui.or.id, 2020). Sehingga dari pernyataan tersebut dapat disimpulkan bahwa investasi di pasar modal syariah itu tidak haram (halal), karena sudah diatur oleh pengawas pasar modal syariah.

\section{c. Terpenuhi kualifikasi halal}

Islam sendiri telah memperbolehkan dan menganjurkan adanya investasi. Halal sendiri berarti harus memenuhi syarat, baik dari segi zatnya ataupun cara memperolehnya. Terdapat anjuran untuk berinvestasi yang terdapat pada Q.S. Yusuf ayat 46-49 sebagai berikut:

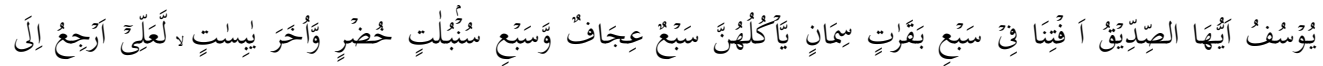

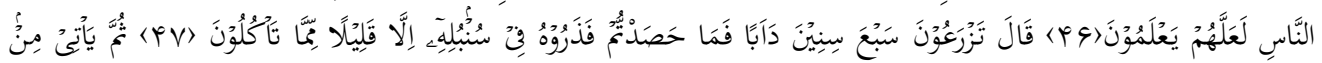

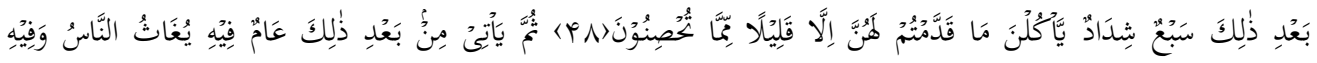

$$
\begin{aligned}
& \text { يَعُصِروُونَ }
\end{aligned}
$$

Artinya:

46)...(Setelah pelayan itu berjumpa dengan Yusuf, dia berseru): "Yusuf, hai orang yang amat dipercaya, terangkanlah kepada kami tentang tujuh ekor sapi betina yang gemuk-gemuk yang dimakan oleh tujuh ekor sapi betina yang kurus-kurus dan tujuh bulir (gandum) yang hijau dan (tujuh) lainnya yang kering agar aku kembali kepada orang-orang itu, agar mereka mengetahuinya." 
47) Yusuf berkata: "Supaya kamu bertanam tujuh tahun (lamanya) sebagaimana biasa; maka apa yang kamu tuai hendaklah kamu biarkan dibulirnya kecuali sedikit untuk kamu makan.

48) Kemudian sesudah itu akan datang tujuh tahun yang amat sulit, yang menghabiskan apa yang kamu simpan untuk menghadapinya (tahun sulit), kecuali sedikit dari (bibit gandum) yang kamu simpan.

49) Kemudian setelah itu akan datang tahun yang padanya manusia diberi hujan (dengan cukup) dan di masa itu mereka memeras anggur." (QS. Yusuf, (12): 46-49, n.d.)

Ayat ini memberikan pelajaran untuk tidak menggunakan semua kekayaan yang dimiliki saat kita telah memperolehnya, tetapi hendaknya sebagian kekayaaan yang diperoleh itu juga kita tangguhkan pemanfaatannya untuk keperluan yang lebih penting. Dengan kata lain, ayat ini mengajarkan untuk mengelola dan mengembangkan kekayaan demi menyiapkan masa yang akan datang (Nurlita, 2014: 18). Anjuran tersbut menbawa pernyataan Widya Rahmaida dan Wahyu Rizki Febriyanti:

"...Investasi di Pasar Modal Syariah halal, karena saham perusahaan yg diperdagangkan dalam pasar modal syariah sudah memenuhi kualifikasi saham syariah. Kemudian dari segi proses pembelian sahamnya, setahu saya perusahaan sekuritas tidak memfasilitasi pembelian saham dengan berhutang. Sehingga tidak ada bunga yg dikenakan dalam transaksinya."

Pendapat serupa juga diungkapkan oleh Dwi Nor Safitri yang menyebutkan bahwa:

"...investasi di pasar modal syariah sudah terjamin halal, karena sekuritas-sekuritas yang terdapat pada pasar modal syariah sudah terstandarisasi kehalalannya."

\section{d. Pengetahuan yang tepat mengenai investasi}

Hal ini ditandai dengan telah adanya persepsi baik oleh masyarakat tentang investasi di Pasar Modal Syariah, masyarakat telah mengetahui keuntungan jangka panjang yang didapat dengan berinvestasi di Pasar Modal Syariah. Hal ini sepadan dengan yang diungkapkan oleh Risalatul Mu'ayanah, Fachrizaman Izzulhaq, Wilda Yusroh: modal syariah."

"...kita tahu aturan-aturan yang diperdagangkan dalam pasar 
Dengan adanya hal tersebut membuktikan bahwa edukasi telah tepat sasaran namun masih perlu adanya peningkatan di berbagai aspek kehidupan. Hal itu di respon oleh Bursa efek Indonesia terkait peningkatan literasi investasi di pasar modal melalui game. Game nabung saham go merupakan permainan simulasi transaksi di pasar modal. Game ini meningkatkan literasi pengguna (Hana, 2019) yakni mengetahui sistem perdagangan, jam transaksi, informasi portofolio dan beberapa informasi lainnya. Sehingga game tersebut dapat digunakan sebagai media untuk meningkatkan literasi investasi di masyarakat terutama di kalangan pemuda.

\section{Persepsi keharaman Investasi di Pasar Modal Syariah}

Minat masyarakat terhadap investasi saham syariah belum banyak karena masyarakat belum mengetahui dan memahami seperti apa saham syariah. Investasi syariah pada dasarnya termasuk dalam keuangan syariah yaitu seluruh ketentuan di dalamnya menggunakan suatu sistem yang pelaksanaannya berdasarkan hukum syariah. Perdagangan saham syariah merupakan salah satu produk investasi syariah. Banyak anggapan bahwa berinvestasi itu judi dan spekulasi sehingga dilarang dalam ajaran Islam (Selasi, 2018: 93).

Adapun persepsi haram muncul dari mayoritas masyarakat yang belum teredukasi mengenai investasi di Pasar Modal Syariah. Ada satu alasan yang melatarbelakangi anggapan haram tersebut, yaitu adanya unsur ketidakpastian. Ketidakpastian yang dimaksud adalah mengenai jumlah keuntungan dan kerugian dari transaksi tersebut. Dengan adanya ketidakpastian tersebut membuat enggannya masyarakat untuk ikut berkontribusi dalam investasi di pasar modal syariah. Hal ini terbukti dalam hasil wawancara salah satu informan yaitu Roiazzaqia sebagai berikut:

"...investasi di pasar modal syariah dikatakan haram karena mengandung unsur ketidakpastian, misalnya dalam masalah untung ruginya. Dan hal yang diharamkan di pasar modal syariah karena mengandung unsur riba."

Persepsi tersebut muncul dari ketakutan-ketakutan masyarakat untuk mengambil risiko dan stigma buruk tentang investasi itu merugikan. Pandangan dari salah satu informan perlu diluruskan dengan adanya edukasi secara detail mengenai investasi di Pasar Modal Syariah.

\section{Persepsi keraguan Investasi di Pasar Modal Syariah}

Persepsi ini muncul akibat kurangnya pengetahuan tentang investasi itu sendiri baik dari segi konvensional maupun dari segi syariah. Hal ini terbutkti dari pernyataan Safinatun Najah: 
“...masih meragukan kehalalan investasi tersebut karena belum memahami bagaimana sistem dalam Pasar Modal Syariah. Dan juga ada kemungkinan sistemnya sama seperti pasar modal konvensional, namun berlabel syariah."

Pendapat lain diungkapkan karena adanya keraguan berinvestasi karena belum mengetahui investasi secara syariah. Hal ini diungkapkan oleh Anis Fitria, Salma Nuryana, Muhammad Fahmi, Khusna Rofiatul, Kholiluddin Achmad yang mengungkapkan bahwa:

"...investasi di pasar modal syariah masih meragukan, karena belum diketahui saham syariah itu memang terhindar dari investasi yang dilarang atau tidak. Jika investasi tersebut haram berarti disitu menjalankan usaha yang merusak moral atau bersifat mudarat. Namun juga ada yang mengatakan halal karena, Keuntungan halal yang investor syariah dapatkan sama seperti investor saham konvensional, yaitu berupa capital gain yaitu keuntungan investasi yang berasal dari selisih harga jual dan beli, serta deviden yaitu bagi hasil dari keuntungan perusahaan."

Alasan lain dikarenakan adanya perbedaan pendapat mengenai halal atau haramnya berinvestasi. Jadi masyarakat merasa kebigungan. Hal ini terbukti dari pernyataan dari Aliyya Ishlah Farah:

“...masih meragukan karena masih banyak perbedaan pendapat tentang investasi di pasar modal syariahdan mungkin investasi tersebut belum memenuhi syarat dalam prinsip-prinsip syariah."

Dari beberapa informan tersebut dapat disimpulkan bahwa persepsi buruk muncul akibat dari ketidaktahuan masyarakat mengenai Investasi di pasar modal syariah itu sendiri. Persepsi tersebut dapat berubah apabila sosialisasi dan edukasi telah tepat sasarannya pada semua aspekaspek kehidupan masyarakat, baik dari aspek akademisi maupun aspek yang lainnya.

\section{KESIMPULAN}

Edukasi tentang investasi di pasar modal syariah terhadap semua aspek kehidupan perlu ditingkatkan, sebab dari data yang diperoleh, masyarakat berpendapat bahwa investasi di pasar modal adalah haram karena wawasan masyarakat tentang pasar modal syariah dianggap sangat kurang. Sebagian informan menyebutkan bahwa persepsi akan berubah setelah mendapatkan edukasi mengenai investasi di pasar modal syariah secara jelas. Jadi perdebatan-perdebatan tentang halal dan haramnya investasi di Pasar Modal Syariah tidak perlu ada. 


\section{DAFTAR PUSTAKA}

Direktorat Pasar Modal Syariah, \& Keuangan, O. J. (2020). http://www.ojk.go.id/id/kanal/syariah/Documents/Pages/-Statistik-SahamSyariah--Januari-2020/Statistik\%20Saham-2020\%20Januari.pdf.

Dyarini. (2012). Investasi Saham dalam Perspektif Islam. IQTISHAD, 12(27), 40-54.

Farid, M., \& Adib, M. (2018). Fenomenologi Dalam Penelitian Ilmu Sosial.

Gerald, F. (1978). Public Sector Investment Planning for Developing Country (First Edit). Madras: The MacMillan India Press Ltd.

Hana, K. F. (2018). Dialektika Hukum Trading Saham Syariah di Bursa Efek Indonesia. Tawazun: Journal of Sharia Economic Law, 1(2), 148-160. Retrieved from http://journal.stainkudus.ac.id/index.php/tawazun/index

Hana, K. F. (2019). Efektifitas Literasi Melalui Game Nabung Saham Go Terhadap Keputusan Membeli Saham Syariah. EQUILIBRIUM: Jurnal Ekonomi Syariah, 7(2), 367-385. Retrieved from journal.stainkudus.ac.id/index.php/equilibrium\%0AEfektifitas IPOT.

https:/ / www.indopremier.com/ipotnews/newsDetail.php?jdl=Saha m_itu_Bukan_Barang_Haram\&news_id=104182\&group_news=IPOT NEWS\&news_date=\&taging_subtype $=$ STOCKEDUCATION\&name $=$ \&search=y_general\&q=saham $\% 20$ syariah, \%20saham \% 20halal,\&hala man=1.

Lopa, Z. L. A., \& Manggu, S. A. (2019). Pengaruh Pengetahuan, Persepsi, dan Preferensi Risiko Masyarakat di Kabupaten Majene terhadap Minat Berinvestasi di Pasar Modal. Majalah Neraca, 17-34.

Malik, A. D. (2017). Analisis Faktor-Faktor Yang Mempengaruhi Minat Masyarakat Berinvestasi Di Pasar Modal Syariah Melalui Bursa Galeri Investasi UISI. Jurnal Ekonomi Dan Bisnis Islam, 3(1), 61-84.

Manulife Asset Management. (2015). Behavioral Finance-Reksa Dana Manulife.

Mubarok, F. K. (2018). Peran Sosialisasi dan Edukasi dalam Menumbuhkan Minat Investasi di Pasar Modal Syariah. INOVASI, $14(2), 113-122$.

Novita, I. (2020). http://www.republica.co.id/berita/q650zz370/investasi-syariahmeningkat-kantongi-70132-investor.

Nurlita, A. (2014). INVESTASI DI PASAR MODAL SYARIAH DALAM KAJIAN ISLAM. Jurnal Penelitian Sosial Keagamaan, 17(1), 5-6.

Pardiansyah, E. (2017). Investasi dalam Perspektif Ekonomi Islam: Pendekatan Teoritis dan Empiris. Jurnal Ekonomi Islam, 8(2), 337-373.

Puspitaningtyas, Z. (2013). Perilaku Investor dalam Pengambilan Keputusan Investasi di Pasar Modal Syariah. Prosiding Seminar 
Nasional, 6.

Putra, T. W. (2018). Investasi dalam Ekonomi Islam. Jurnal Ulumul Syar'i, $7(2), 49-57$.

QS. Yusuf, (12): 46-49.

Ricciardi, V., \& Simon, H. K. (2000). What is Behavioral Finance? Business, Education, and Technology Journal Fall.

Selasi, D. (2018). Ekonomi Islam; Halal dan Haramnya Berinvestasi Saham Syaria. Jurnal Ekonomi Syariah Dan Bisnis, 1(2), 87-96.

Simbolon, M. (2008). Persepsi dan Kepribadian. Ekonomi Dan Bisnis, 2(1), 52-66.

Wiyanti, D. (2013). Perspektif Hukum Islam terhadap Pasar Modal Syariah Sebagai Alternatif Investasi Bagi Investor. Jurnal Hukum IUS QUIA IUSTUM, 20(2), 234-254.

www.dsn.mui.or.id. (2020).

www.ojk.go.id. (n.d.). 